\title{
İran-Irak Savaşı'nda Kullanılan İran Propaganda Posterlerinin Göstergebilimsel Analizi
}

\author{
Caner Çak1*
}

\section{Öz}

İran-Irak Savaşı, dünya tarihindeki en kanlı savaşlardan biri olmuştur. 22 Eylül 1980 yılında Irak Devlet Başkanı Saddam Hüseyin önderliğinde Irak Ordusu’nun İran sınırını geçmesiyle başlayan savaş, 20 Ağustos 1988 yılında ilan edilen ateşkes ile son bulmuştur. Savaşın sonunda her iki taraftan yüz binlerce kişi hayatını kaybetmiştir. İran Devrimi'nden bir yıl sonra meydana gelen savaşta İran, halkını Irak Ordusu'na karşı seferber ederken yoğun bir propaganda faaliyeti yürüttü. Özellikle bu savaşta İran, kamuoyunda Irak'a karşı destek bulabilmek için propaganda amaçlı posterleri etkin bir şekilde kullandı. Bu çalışmada, İranIrak Savaşı'nda kullanılan propaganda amaçlı posterler içerisinden Chicago Üniversitesi tarafından belirlenen 8 propaganda afişi, nitel araştırma yöntemleri içerisinde yer alan göstergebilimsel analiz yöntemine tabi tutularak incelemiştir. Posterlerin göstergebilimsel analizi Fransız Dil Bilimci Roland Barthes'ın düzanlam, yananlam ve mit kavramları ışığında yapılmıştır. Elde edilen bulgular ışığında, İran'ın, ABD ve Irak'a karşı nefret söylemi inşa ederek İran halkını Irak Ordusu'na karşı seferber etmeye çalıştığı görülmüştür.

Anahtar Kelimeler: Propaganda, İran, Savaş, Poster, Göstergebilim

Arş. Gör., İnönü Üniversitesi İletişim Fakültesi, caner.caki@inonu.edu.tr. 


\title{
The Semiotics Analysis of Iran Propaganda Posters Used in Iran-Iraq War
}

\author{
Caner Çaki* ${ }^{*}$
}

\begin{abstract}
The Iran-Iraq War was one of the bloodiest battles in world history. The war, which began on 22 September 1980, when the Iraqi army crossed the Iranian border under the leadership of Saddam Hussein, ended with a ceasefire declared on 20 August 1988. At the end of the war, hundreds of thousands of people from both sides lost their lives. In the war that took place a year after the Iranian Revolution, Iran carried out intense propaganda activities while mobilizing its people against the Iraqi Army. Especially in this war, Iran effectively used propaganda posters to find support against Iraq in public. In this study, 8 propaganda posters determined by Chicago University among the propaganda posters used in the Iran-Iraq War were examined by the semiotical analysis method in the qualitative research methods. The semiotical analysis of the posters was made in the light of the French Language Scientist Roland Barthes' concepts of détonation, connotation and myth. In the light of the findings, it was seen that Iran tried to mobilize the Iranian people against the Iraqi Army by building hate speech against the USA and Iraq.
\end{abstract}

Keywords: Propaganda, Iran, War, Poster, Semiotics

\footnotetext{
* Res. Asst., İnönü University, Faculty of Communication, caner.caki@inonu.edu.tr.
} 


\section{Giriş}

1980 yılının başında Irak’ta iktidarda bulunan Baas Partisi, İran'ın Irak nüfusunun çoğunluğunu oluşturan Şii nüfusu Irak'ta iktidarda bulunan Sünni yönetime karşı kışkırtmasından çekinmekteydi. Diğer yandan Irak Devlet Başkanı Saddam Hüseyin, İran'ın zengin petrol yataklarına sahip Huzistan Bölgesi üzerinde hak talep ediyordu. Bu amaçla Irak, devrimden yeni çıkan ve rehine krizi nedeniyle ABD ile ilişkileri bozulan İran'ın topraklarına karşı genel bir saldırı başlattı. İran, Irak'ın ani saldırısına karşı tüm ülkede genel bir seferberlik ilan ederek, halkını Irak Ordusu'na karş1 savaşmaya çağırdı. Bu amaçla İran, halkın topyekun bir savaşa girmesi için elindeki tüm kitle iletişim araçlarını Irak yönetimine karşı nefret söylemi inşa etmek için kullandı. Bu süreçte, İran yönetimi tarafindan posterler propaganda amaçlı etkin bir şekilde kullanıldı. Kullanılan posterlerde İran'da kurulan yeni yönetimin ideolojik tüm söylemleri hakimdi. Bu ça1ışmada, İran-Irak Savaşı'nda İran yöntemi tarafindan propaganda amaçlı kullanılan posterler göstergebilimsel analiz yöntemi ile ele alınmıştır.

Çalışma kapsamında aşağıdaki sorular sorulmuştur;

İran-Irak Savaşı'nda İran tarafından propaganda amaçlı kullanılan posterlerde;

- Temel olarak hangi konular işlenmektedir?

- Irak'a yönelik nefret söylemi kim veya kimler üzerinden inşa edilmektedir?

- Propaganda amaçlı hangi mitler inşa edilmektedir?

- Hangi metonimi, metafor, kod ve simgelerden yararlanılmıştır?

Son yıllarda yapılan çalışmalarda farklı dönemlerde propaganda amaçlı kullanılan posterlerin göstergebilimsel analiz yöntemi 1şı̆̆ında incelendiği görülmektedir. Bu çalışmalar içerisinde; Çakı ve Gülada,, "Vichy Fransası'nda İşgal Propagandası" adlı çalışmada 2. Dünya Savaşı'nda kurulan Vichy Fransası'nda propaganda posterlerinin işgal propagandası bağlamında nasıl kullanıldığını Barthes'ın düzalam ve yananlam boyutunda göstergebilimsel analiz yöntemi kullanarak ele almıştır. Çalışma, amaçlı örneklem metodu kullanılarak belirlenen 8 propaganda amaçlı poster üze-

Caner Çakı ve Mehmet Ozan Gülada, "Vichy Fransası'nda İşgal Propagandası”. Trakya Üniversitesi İktisadi ve İdari Bilimler Fakültesi Dergisi 7, no.1, (Temmuz 2018): 53. 
rinden yürütülmüştür. Çalışma sonucunda Vichy Fransa'sının, Müttefik Devletleri'ne karşı nefret söylemi inşa ederek Fransız halkından destek bulmaya çalıştığı ortaya çıkmıştır.

Boyraz ve Cantürk,2 "Amerika Birleşik Devletleri Örnekleminde İkinci Dünya Savaşı Dönemi Askeri Propaganda Posterleri” adlı çalışmada ABD tarafindan 2. Dünya Savaşı'nda kullanılan propaganda amaçlı posterler göstergebilimsel analiz yöntemi ile incelemiştir. Elde edilen bulgular 1ş1ğında, ABD'nin posterlerde "görsel ağırlıklı" olarak Amerikan kamuoyunu etkileyebilmek için, özgürlük, bağımsızlık ve vatanseverlik vurgusu yaptığı ortaya çıkmıştır.

Çak1, ${ }^{3}$ "Nazi Almanyası Etkisindeki İtalyan Sosyal Cumhuriyeti'nin Propaganda Posterleri Üzerine İnceleme" adlı çalışmada Faşizm ideolojisi altında yönetilen İtalyan Sosyal Cumhuriyeti'nin propaganda faaliyetleri, propaganda amaçlı posterler üzerinden göstergebilimsel analiz yöntemi kullanılarak ele almıştır. Çalışma sonucunda, İtalyan propagandasında Nazi Almanyası'nın kamuoyunda dost ve müttefik olarak yansıtılmaya çalış1ldığ1 görülmüsşür.

Propaganda amaçlı posterlerin göstergebilimsel açıdan incelendiği çalışmalarda, genel olarak egemen ideolojilerin hakim kılındığı ve yüceltildiğgi; karşıt görüşlere yönelik ise nefret söylemlerinin inşa edilmeye çalışıldığ sonucuna ulaşılmıştır. Nitekim, çalışma kapsamında ele alınan İran propaganda amaçlı posterlerinde de İran'daki Humeyni rejiminin değerlerinin yüceltildiği buna karşın Saddam yönetimine karşı da nefret söylemi inşa edildiği görülmüştür. Bu açıdan çalışmada elde edilen bulguların, yapılan önceki çalışmalar ile benzerlikler taşıdığı sonucuna ulaşılmıştır.

Göstergebilim sosyal bilimlerde film, fotoğraf, müzik, resim gibi pek çok alanın analiz yöntemi olarak kullanılmaktadır. Nitekim son dönem göstergebilim yönteminin kullanıldığı alanda önemli çalışmalar yapılmaktadır.

Burak Boyraz ve Ali Cantürk, "Amerika Birleşik Devletleri Örnekleminde İkinci Dünya Savaşı Dönemi Askeri Propaganda Posterleri”. Uluslararası Sosyal Araştırmalar Dergisi 7, no.3, (2014): 496.

3 Caner Çakı, "Nazi Almanyası Etkisindeki İtalyan Sosyal Cumhuriyeti'nin Propaganda Posterleri Üzerine İnceleme”. Selçuk Üniversitesi İletişim Fakültesi Akademik Dergisi 11, no.2, (2018): 252. 
Bunlar içerisinde: Erol vd., "Hitler Dönemi Eğitim Yapısındaki Otokrasinin Eleştirisi: Die Welle Filmi Üzerine Göstergebilimsel İnceleme" adlı çalışmada Nazi Almanyası dönemi eğitim yapısını Die Welle adlı sinema filmi özelinden göstergebilimsel analiz yöntemi kullanarak incelemiştir. Çalışma sonucunda nasyonal sosyalist eğitim yapısının ağır bir şekilde eleştirildiği görülmüştür.

Çak1 (2018), ${ }^{5}$ "Sovyetler Sonrası Rus Sinemasında Komünizm İdeolojisi: Amiral Filmi ve Göstergebilimsel Analizi" adlı çalışmada günümüz Rus sinemasında Komünizm ideolojisinin nasıl ele alındığını Fransız Dil Bilimci Algirdas Julien Greimas'nn Eyleyenler Örnekçesi'ne göre Amiral filmi üzerinden incelemiştir. Çalışmada, Komünizm ideolojisinin filmde ağır bir eleştiriye maruz bırakıldığ 1 sonucuna ulaşılmıştır.

Arpa (2018), ${ }^{6}$ "İş Güvenliğini Konu Alan Kamu Spotu Reklamlarında Korku Çekiciliği Kavramının Kullanılması” adlı çalışmada Barthes'ın göstergebilimsel anlayışı doğrultusunda iş güvenliğini konu alan reklam videolarını göstergebilimsel analize tabi tutmuştur. Elde edilen bulgularda, çalışanların iş güvenliği konusunda yeterli önlem alabilmeleri için korku çekiciliği kavramının sıklıkla kullanıldığı görülmüştür.

Tanyeri Mazıcı ve Çakı, " "Adolf Hitler'in Korku Çekiciliği Bağlamında Kamu Spotu Reklamlarında Kullanımı” adlı çalışmada korku çekiciliği bağlamında otoriter liderlerin kullanımını kamu spotu reklamları üzerinden Barthes'ın mit kavramı çerçevesinde göstergebilimsel analiz yöntemi kullanarak incelemiştir. Çalışmada, Hitler'in kamu spotu reklamlarında "tehlike" ve "tehdit" metaforları olarak kullanıldığı sonucuna ulaşı1mıştır.

Çakı vd. (2018), ${ }^{8}$ "Horst-Wessel Propaganda Marşı Üzerinden Nazizm İdeolojisinin İnşası" adlı çalışmada İsviçreli Dil Bilimci Ferdinand de

Ebru Gülbuğ Erol, Necati Cerrahoğlu \& Caner Çakı, "Hitler Dönemi Eğitim Yapısındaki Otokrasinin Eleştirisi: Die Welle Filmi Üzerine Göstergebilimsel İnceleme”, IX. Uluslararası Eğitim Araştırmaları Kongresi, Ordu, (2017): 1234.

5 Caner Çakı, "Sovyetler Sonrası Rus Sinemasında Komünizm İdeolojisi: Amiral Filmi ve Göstergebilimsel Analizi”. Uluslararası Sosyal Bilimler Dergisi 1, no.1, (2018): 53.

6 Murat Arpa, "İş Güvenliğini Konu Alan Kamu Spotu Reklamlarında Korku Çekiciliği Kavramının Kullanılması”, Uluslararası Sosyal Bilimler Dergisi 1, no.2, (2018): 105.

7 Emel Tanyeri Mazıcı ve Caner Çakı, "Adolf Hitler'in Korku Çekiciliği Bağlamında Kamu Spotu Reklamlarında Kullanımı”. Erciyes İletişim Dergisi 5, no.3, (2018): 290.

8 Caner Çak1, Derya Karaburun Doğan \& Nurcan Yılmaz, "Horst-Wessel Propaganda Marşı Üzerinden Nazizm İdeolojisinin İnşası”. İletişim Kuram ve Araştırma Dergisi 1, no.46, (2018): 89. 
Saussure'ün gösteren ve gösterilen kavramları üzerinden müziğin propaganda amaçlı kullanımını ele almıştır. Çalışma sonucunda, propaganda marşlarında Nazizm ideolojisinin yüceltildiği görülmüştür.

Türkiye'de yapılan göstergebilim çalışmalarında, Barthes, Saussure, Greimas ve Lévi-Strauss'un göstergebilimsel anlayışları üzerinden incelemelerde bulunulduğu görülmektedir. Yapılan çalışmalarda, film, müzik, resim vb. alanlarda verilmek istenen mesajların içerikleri yorumlanmıştır.

Yapılan kapsamlı literatür çalışması sonucunda, 1980 yılından günümüze kadar etkisini sürdüren İran-Irak Savaşı'nda kullanılan propaganda yöntemleri ile ilgili alanda herhangi bir çalışmaya rastlanılmamıştır. Bu amaçla çalışma kapsamında devrimden bir yıl sonra Irak tarafından büyük bir saldırıya uğrayan İran'ın, halkını Irak Ordusu'na karşı topyekûn bir savaşa yönlendirirken propaganda amaçlı posterlerden nasıl yararlandığı ele alınmiştır.

\section{2. İran-Irak Savaşı'na Genel Bir Bakış}

1979 yılında, gerçekleşen İran İslam Devrimi'nden sonra İran'da Ayetullah Ruhullah Humeyni önderliğinde Şiî mezhebi görüşlerini esas alan İran İslam Cumhuriyeti kuruldu. Böylece İran' da yüzlerce yıl süren monarşi son bulmaktaydı. Humeyni Yönetimi'nin Batı karşıtı politikaları, İran'ın Şah döneminde olumlu olan Batı ülkeleri ile ilişkilerini yeni dönemde kopma noktasına getirdi. ${ }^{9}$ Diğer yandan ABD'nin sürgündeki İran Şahı'nı ülkesine kabul etmesi ve akabinde İran'da yaşanan rehine krizi Batılı devletlerin İran'a karşı tavır almasına yol açtı. ${ }^{10}$ Humeyni'nin uyguladığ ${ }^{1}$ dış politika kısa sürede İran'ın uluslararası siyasette yalnız kalmasına yol açtı.

Humeyni yönetimi, iç işlerinde de sert ve radikal kararlar almaktaydı. Nitekim, İran'da yaşanan devrimden sonra ülkede Humeyni'ye muhalif binlerce isim tutuklandı, bazıları idam edildi. Humeyni yönetimi, ülkede yeni rejimin güçlenmesini sağlamak için orduda tehlikeli görülen isimleri de ortadan kaldırdı. Şah döneminde hizmet veren başta SAVAK (Milli İstih-

$9 \quad$ Rouhollah K. Ramazani, "Revolutionary Iran: Challenge and Response in the Middle East” (Baltimore: Johns Hopkins University Press,1986), 111.

10 Barış Doster,’Bir Bölgesel Güç Olarak İran'ın Ortadoğu Politikası”. Ortadoğu Analiz 4, no.44, (2012): 46. 
barat ve Devlet Güvenlik Örgütü) olmak üzere tüm askeri birimler yeniden düzenlendi. İran'da rejime bağl1 Devrim Muhafızları adı altında yeni bir askeri yapılanma meydana getirildi. ${ }^{11}$ Humeyni yönetiminin orduya yönelik gerçekleştirdiği faaliyetler uluslararası alanda İran'ın askeri olarak güçsüz duruma düştüğü algısını oluşturdu.

İran İslam Devrimi'nin gerçekleştiği 1979 yılında Saddam Hüseyin, Irak Devlet Başkanı olmuştu. Saddam'ın devlet başkanı olması ile birlikte Irak yönetimi, İran İslam Cumhuriyeti'ne karşı bir siyaset izleme yoluna gitti. Saddam, İran'ın Irak'taki Şii nüfus üzerine etki etmesinden çekinmekteydi. Diğer yandan İran'ın zengin petrol yataklarının bulunduğu Huzistan Bölgesi'nde Saddam yönetimi hak talep etmekteydi. Saddam, İran'in ordusunda yaşanan tasfiyeler ve uluslararası alanda yalnızlık içerisine düşmesinden yararlanmak amacıyla 22 Eylül 1980 tarihinde İran topraklarına saldırd1. ${ }^{12}$ Irak'ın İran'a saldırmasından sonra başta Arap ülkeleri olmak üzere, Irak'a çeşitli ülkelerden destek geldi.

Saddam'ın yönetimindeki Irak Ordusu, savaşın ilk günlerinde elde ettiği başarılara rağmen İran'ın iç bölgelerine kadar ilerleyemedi. Diğer yandan kuşatma altına alınan bölgelerin de teslim olması sağlanamadı. Irak'ın kısa sürede zafer elde edememesi, savaşın her iki taraf içinde uzun bir yıpratma savaşına girmesine yol açtı. İki ülke birbirine karşı üstün gelebilmek için tüm kaynaklarını savaş için seferber etti. Buna karşın savaşta iki tarafta birbirine karşı üstünlük sağlayamadı. Saddam yönetiminin İran'ın teslim olmasını sağlamak için kullandığı kimyasal silahlar da savaşın gidişatını değiştiremedi ${ }^{13}$ Buna karşıı Irak tarafindan kullanılan kimyasal silah, asker ve sivil pek çok İranlının olumsuz yönde etkilenmesine yol açtı.

Bu süreçte Irak, İran'ın savaştan çekilmesini sağlayabilmek için Basra Körfezi'nde petrol taşıyan İran gemilerine saldırılar düzenledi. Irak'ın petrol bölgesine yönelik gerçekleştirdiği saldırılardan olumsuz yönde etkilenen ABD ve Avrupa ülkeleri savaşın sonlanması için girişimde bulundu.

11 Leman Nida Yıldırım, "1979 İran Devrimi Özelinde Muhafazakârlık İdeolojisinin Eleştirisi: Persepolis Filmi ve Göstergebilimsel Analizi”. Uluslararası Sosyal Bilimler Dergisi 1, no.1, (2018): 33.

12 Gül İnanç, Türk Diplomasisi’nde Irak (1978-1997) (İstanbul: Türkiye İş Bankas1 Yayınlar1, 2008), 13.

13 L. Thomas McNaugher, "Ballistic Missiles and Chemical Weapons: The Legacy of the Iran-Iraq War”. International Security 15, no.2, (1990): 16. 
ABD Donanması bölgeye konuşlandırıldı. İran, Irak gibi zafer kazanmak için sonuna kadar savaşma taraftarıyd $1 .{ }^{14} \mathrm{Bu}$ yüzden, iki tarafı da uzlaştırmak için yapılan tüm barış görüşmeleri sonuçsuz kaldı ve savaş Irak ve İran'ın ateşkes ilanında bulunduğu 1988 yılına kadar sürdü. ${ }^{15}$ İki ülke arasında 8 yıl süren savaşın sonucunda sınırlar değişmedi. Buna karşın iki tarafta da yüz binlerce asker ve sivil hayatını kaybetti. İki ülke savaşın giderlerini karşılamak için büyük ekonomik yaptırımlar altında girdi. Bunun yanında petrol bölgelerine yönelik yapılan saldırılar sonucunda dünya petrol üretimi ciddi oranda düşüş yaşadı. Bu düşüş dünya petrol fiyatlarının yükselmesine yol açtı.

\section{3. İran-Irak Savaşı'nda İran Propaganda Faaliyetleri}

22 Eylül 1980 yılında Irak Ordusu'nun sürpriz bir şekilde İran'a saldırması üzerine, İran dini lideri Ayetullah Humeyni ülkede genel bir seferberlik ilan etti. Bu amaçla ülke genelinde Irak'a karşı topyekun bir savaş hazırl1ğ1 başlatıld1. Savaş döneminde, Humeyni yönetiminin Irak'a yönelik propaganda faaliyetlerinde İranlı din adamları (mollalar) büyük rol üstlendi. Mollalar, Irak, ABD ve Batı karşıtı söylemlere yönelerek İran halkını Irak Ordusu'nun saldırılarına karşı birlik olmaya çağırdı. İran'ın propaganda faaliyetleri zaman içerisinde meyvesini vermiş, ülke içerisinde Humeyni yönetimine karşı muhalif olan gruplar da Irak Ordusu'nun saldırılarına karşı birlik olmuştu. ${ }^{16}$ Bu yolla devrimden sonra ülkede sağlanmaya çalış1lan birliğin de kısmi olarak gerçekleştiği görüldü.

İran propagandasının ülke içerisinde yakaladığı başarının uluslararası alanda da sürdüğü pek kabul edilmemektedir. Bunun temel nedeni İran'ın uluslararası alanda uyguladığı "Ne Batı ne Doğu" politikası gereği kendini önemli ölçüde diğer ülkelerden izole etmesidir. Bu yüzden İran'ın uluslararası destek bulması ve propaganda faaliyetlerini yürütmesi için ihtiyaç duyduğu dost ve müttefik ülke sayısı oldukça sınırlı kalmaktayd $1{ }^{17}$

14 Ünal Gündoğan, "Geçmişten Bugüne İran İslam Devrimi: Genel Değerlendirme.” Ortadoğu Analiz 3, no.29, (2011): 99.

15 Ünal Gündoğan, “1979 İran İslam Devrimi’nin Ortadoğu Dengelerine Etkisi”. Middle Eastern Analysis / Ortadogu Analiz 3, no.30, (2011): 70.

16 İsmail Yurdakurban, Devrim Sonrası İran D1ş Politikası (1979-2005), Yayınlanmamış Yüksek Lisans Tezi, Selçuk Üniversitesi Sosyal Bilimler Enstitüsü, Konya, (2007), 23.

17 Efraim Karsh, The Iran-Iraq War (USA: The Rosen Publishing Group, 2009), 84. 
İran'ın Arap dünyasında propaganda faaliyetini yürüteceği ülke sayısı da oldukça sınırlıydı. Nitekim, Arap ülkelerinin nüfusunun çoğunluğu Sünni mezhebine mensup Müslümanlardan oluşmaktaydı. Bu yüzden Irak'ta Saddam'ın Sünni idaresi Arap ülkeleri tarafından destek görürken, İran'da Humeyni'nin Şii yönetimine karşı mesafeli durulmaktaydı. Diğer yandan Irak, Arap nüfusun çoğunlukta olduğu bir ülkeydi. İran'da ise Fars nüfus hakimdi. ${ }^{18} \mathrm{Bu}$ nedenle İran propagandası Arap ülkeleri üzerinde -Libya ve Suriye haricinde- yeterince etkili olamamaktaydı.

Bu süreçte İran, başta Orta Asya'da Sovyetler Birliği'ne bağlı Müslüman ülkeler olmak üzere, İslam toplulukları üzerinde savaşta kendisini haklı göstermek amacıyla dini söylemlerin ağıllıkta olduğu yoğun bir propaganda çalışması yürüttü. ${ }^{19}$ Böylece İran, Arap ülkelerinin dışında kendisine Müslüman ülkelerden uluslararası alanda destek bulma yoluna gitti.

Humeyni yönetimi, Irak Ordusu'nun saldırılarını ülkede kurmuş olduğu yeni rejimin meşruiyetini sağlamak amacıyla etkili bir propaganda aracı olarak kullanma yoluna gitti. Rejim, Irak'a karşı yürütülen savaşın İran halkı gözünde kutsal bir konumda olması için çalışıyordu. Bu amaçla İran propagandasında dini söylemlere sıklıkla yer verilmekteydi. ${ }^{20}$ İan aynı zamanda Irak yönetiminin propaganda faaliyetlerine de karşı mücadele etmek zorunda kalmaktaydı. Nitekim, Irak hükümeti, İran rejimini "Humeyni tarafından yönetilen Farslı büyücüler" şeklinde itham edecek kadar ileri gidebilmekteydi. ${ }^{21}$ İran propagandası, buna karşı Saddam'1 ve partisini itibarsızlaştırma yoluna gitti. Bu dönemde İran'daki tüm kitle iletişim araçları Humeyni yönetiminin denetimindeydi. Bu amaçla televizyon, gazete ve radyo gibi dönemin önde gelen kitle iletişim araçları yeni rejimin propaganda faaliyetlerine hizmet etmekteydi.

İran yönetimi tarafindan sinema da İran-Irak Savaşı'nda etkili bir propaganda aracı olarak kullanılmaktaydı. Humeyni döneminde yasaklanacağı düşünülen sinema, aksine rejim tarafindan propaganda aracı olarak kulla-

18 C. Stephen Pelletiere, The Iran-Iraq War: Chaos in a Vacuum (USA: ABC-CLIO, 1992), 60.

19 Dilip Hiro, The Longest War: The Iran-Iraq Military Conflict (New York: Psychology Press, 1991), 63.

20 Ervand Abrahamian, Modern İran Tarihi, Çev. Dilek Şendil. 2. Bask1. (İstanbul: Türkiye İş Bankası Yayınları, 2011), 228.

21 M. S. El-Azhary, The Iran-Iraq War (RLE Iran A) (London: Routledge, 2011), 2. 
nılabilmek için desteklenmişti. Rejimin ülkedeki nüfuzunu arttırabilmesi, yeni kanunların halk tarafından benimsemesi amacıyla propaganda amaçli yararlanılan sinema, İran-Irak Savaşı'nda cepheye taşınmıştı. İran yönetimi, cephelerde savaşan askerleri sinema perdesinden İran halkına yansitmakta, filmlerde hayatını kaybeden askerler ile ilgili kahramanlık hikayelerine yer vermekteydi. ${ }^{22}$

İran propagandasının Irak’ta hedef aldığı unsurlardan biri de Irak’taki Şii nüfustu. Nitekim İran savaşta, Şii nüfusun İran'ın yanında yer almasının Saddam'1 zor duruma düşürebileceğine inanmaktaydı. Bu amaçla İran, savaş sırasında Irak'ta yaşayan Şii nüfusu da desteklemişti. ${ }^{23}$ Böylece İran, Irak'ta da İran İslam Devrimi'ne benzer bir devrimin gerçekleşmesini sağlayabilecek ve Saddam'ın yönetimin Irak'ta sonlanmasını sağlayabilecekti. ${ }^{24}$ İran, Irak'taki Şii nüfusun Saddam'ın Baas Partisi'ne karşı ayaklanmasını teşvik etmekteydi. Humeyni, söylemlerini daha da sertleştirerek Baas Partisi'nin İslam karşıtı bir parti, Saddam'ın da İslam düşmanı bir kişi olduğunu ileri sürmeye başlad1 ${ }^{25}$ Aynı zamanda İran propagandası Irak Ordusu'nun moralini de azaltmayı planlamaktayd $1 .{ }^{26}$ Buna karşın Saddam Irak'ta kendisine karşı çıkan Şii grupları baskı altına almayı başardı ve yönetiminin devrilmesine yol açacak bir ayaklanmanın çıkmasını engelledi.

\section{Yöntem}

Bu çalışmada, İran-Irak Savaşı'nda kullanılan propaganda amaçlı posterler içerisinden Chicago Üniversitesi tarafından belirlenen 8 propaganda afişi göstergebilimsel analiz metodu kullanılarak incelenmiştir. Çalışma kapsamında incelenen propaganda afişlerinde, 8 ana başlık altında İran propagandasındaki temel unsurlar belirlenmiştir. Belirlenen temel unsurları en iyi yansıttığı düşünülen 8 propaganda amaçlı poster de amaçlı örneklem

22 Sabire Batur, Siyasal İslam Sineması Örneğinde İran Sineması Yayınlanmamış, Doktora Tezi: Dokuz Eylül Üniversitesi Güzel Sanatlar Enstitüsü, İzmir, (2007), 96.

23 Kadir Ertaç Çelik, "İslam Devrimi Sonrası İran'da Kimlik ve Dış Politika: Konstrüktivist Bir Bakış”. Bölgesel Çalışmalar 1, no.1, (2016): 266.

24 Efraim Karsh, "Geopolitical Determinism: The Origins of The Iran-Iraq War" Middle East Journal 44, no.2, (1990): 265.

25 M. S. El-Azhary, The Iran-Iraq War (RLE Iran A) (London: Routledge, 2011), 1.

26 David Segal, “The Iran-Iraq War: A Military Analysis”. Foreign Affairs, 66(5), (1988): 948. 
metodu kullanılarak çalışmanın örneklemi olarak seçilmiştir. Bu yüzden Chicago Üniversitesi'nce belirlenen diğer propaganda amaçlı posterler birbirleriyle benzer özellikler taşıması nedeniyle çalışma dışında tutulmuştur. Posterler, Fransız Dil Bilimci Roland Barthes'in düzanlam, yananlam ve mit kavramları ele alınarak analiz edilmiştir.

İran-Irak Savaşı Dönemi'nde devrimden yeni çıkan İran'ın Irak'a karşı yürüttüğü propaganda faaliyetlerini, kullanılan propaganda posterleri üzerinden ortaya koymak çalışmanın temel amacını oluşturmaktadır. Çalışma, İran-Irak Savaşı'nda, İran'ın propaganda faaliyetlerine 1şık tutması bakımından önem taşımaktadır. Nitekim çalışma kapsamında incelenen posterlerde İran İslam Cumhuriyeti'ni ilan eden ve İran'da yüzyıllardır süren monarşiyi sonlandırılan Ayetullah Humeyni önderliğinde İran yönetiminin, posterler üzerinden ideolojik söylemlerini nasıl propaganda aracı olarak kullandığı da ortaya konulmaya çalışılmıştır. Alanda İran Devrimi’nden sonra İran'ın propaganda faaliyetlerini ele alan herhangi bir çalışmaya rastlanılmaması da çalışmayı önemli kılmaktadır.

İran-Irak Savaşı'nda İran'ın propaganda faaliyetlerinin yalnızca İran tarafindan kullanılan propaganda amaçlı posterler üzerinden değerlendirilmesi çalışmanın temel sınırlılığını oluşturmaktadır. Diğer yandan incelenen posterlerin yalnızca Barthes'ın düzanlam ve yananlam temelli göstergebilimsel analiz metodu ile açıklanması da çalışmanın bir diğer önemli sınırlılığını oluşturmaktadır. Nitekim, Ferdinand de Saussure'ün gösteren ve gösterilen temelli Gösterge Modeli, Charles Sanders Peirce'ın Gösterge Kavramı, Algirdas Julien Greimas'ın Eyleyenler Örnekçesi, Claude LéviStrauss'un Karşıtlıklar Modeli olmak üzere alanda farklı göstergebilimsel analiz yöntemleri bulunmaktadır.

Göstergebilim, göstergeler yoluyla oluşan anlamları inceleyen bir bilim da11dır. ${ }^{27}$ Göstergebilim, 20. yüzy1lın başında İsviçreli Dil Bilimci Ferdinand de Saussure ve ABD'li Dil Bilimci Charles Sanders Peirce'in dil bilimi üzerine yaptıkları çalışmalar ile ortaya çıkmıştır. ${ }^{28}$ İlk başlarda göstergebilim, dil alanındaki sınırlı göstergenin çözümlenmesinde kullanılmaktaydı.

27 Caner Çak1, "Mitinglerin Propagandadaki Rolü: Nürnberg Mitingleri'ne Ait Fotoğrafların Göstergebilimsel Analizi”, Maltepe Üniversitesi İletişim Fakültesi Dergisi 5, no.1, (2018): 66.

28 İlhami Sı ̆̆ırcı, Göstergebilim Uygulamaları, Metinleri, Görselleri ve Olayları Okuma (Ankara: Seçkin Yayıncılık, 2016), 30. 
Buna karşın ilerleyen süreçte Fransız Dil Bilimci Roland Barthes'ın ça1ışmaları resim, müzik, film vb. pek çok alanın göstergebilimsel çözümlemeye tabi tutulabilmesini sağladı. Barthes, göstergebilimin geniş bir alana yayılmasının yanında, herkes tarafından anlaşılabilecek olan basitliğe de indirgenmesine yol açtı. Barthes'ın göstergebilime kattığı en önemli kavramlar düzanlam ve yananlam olmuştur. Barthes'a göre göstergeler, düzanlam ve yananlam olmak üzere iki anlam düzlemi üzerinden çözümlenmektedir. ${ }^{29}$ Düzanlam, insanlar tarafından gerçeklik ve yasa olarak kabul edilmektedir. ${ }^{30}$ Yananlam ise, nedensiz ve kültüre özgü olarak kabul edilen anlamı oluşturmaktadır. ${ }^{31}$ Barthes'ın göstergebilimsel çözümlemede üzerinde durduğu bir diğer konu mit kavramıdır. ${ }^{32}$ Mit, belirli bir kültür tarafından doğada gerçeklikleri açıklamak için oluşturulmuş öykülerdir. ${ }^{33}$

Tablo 1. Barthes'ın İkili Anlamlandırma Düzeyi ${ }^{34}$

\begin{tabular}{|c|c|c|}
\hline Birinci Düzey & & İkinci Düzey \\
\hline Gerçeklik-Göstergeler & Gösteren /Gösterilen & Kültür \\
\hline Düzanlam & & Yananlam / Mit \\
\hline
\end{tabular}

Tablo 1'de görüldüğü gibi, Barthes, göstegebilimde anlamlandırma sürecini iki düzeyde ele almıştır. Birinci düzey, gerçekliği ifade eden düzanlam iken, ikinci düzey kültürün inşa ettiği öznel gerçeklikler bütünü olan yananlam ve mit olgusudur. Mit, kültür içerisinde inşa edilen öznel, kültüre ait olguları ifade etmektedir. Barthes, medyayı en belirgin mit üretme arac1 olarak nitelendirmektedir. ${ }^{35}$ Böylece egemen güçler medya yoluyla istedik-

29 Roland Barthes, Göstergebilimsel Serüven. Çev., Mehmet Rifat-Sema Rifat. 8. Bask1, (İstanbul: Yap1 Kredi Yayınları, 2016), 84.

30 Roland Barthes, S/Z. Çev., Sündüz Öztürk Kasar (İstanbul: Sel Yayıncılık, 2016), 19.

31 Hasibe Kalkan Kocabay, Tiyatroda Göstergebilim (İstanbul: E Yayınları, 2008), 35.

32 Mehmet Rifat, Açıklamalı Göstergebilim Sözlüğü: Kavramlar, Yöntemler, Kuramcılar, Okullar (İstanbul: Türkiye İş Bankası Kültür Yayınları, 2013), 40.

33 John Fiske, İletişim Çalışmalarına Giriş. Çev., Süleyman İrvan. 5. Basım (Ankara: Bilim ve Sanat Yayınları, 2017), 185.

34 Fiske, "İletişim", 186.

35 Nazife Güngör, İletişim Kuramlar ve Yaklaşımlar, 2. Bask1 (İstanbul: Siyasal Kitapevi, 2013), 234. 
lerini mitleştirip ideolojik söylemlerini hakim k1labilmektedir. Mitler, egemen güçlerin kontrolünde yapay gerçeklikleri inşa edebilmektedir. Mitler yoluyla egemen güçlerin istedikleri doğru, istemedikleri ise yanlış olarak gösterilmektedir. Diğer yandan mit kültüre ait öznel değerler olduğu için, bir kültür içerisinde inşa edilen mitte doğru kabul edilen değerler, diğer bir kültürün mitinde yanlış olarak değerlendirilebilmektedir. Aynı şekilde egemen güçler mit olgusunda dost ve düşman algısını da belirleyebilmektedir.

Barthes'ın göstergebilimsel analizlerinde ön plana çıkan diğer iki önemli kavram metafor ve metonimidir. Metafor, bir sözcügün yerleşmiş anlamının yerine onun değişik anlamlı başka bir sözcüğün yerine kullanılmasıdır. Örneğin, terazinin adalet kavramını temsil etmesi. Metonimi ise, birbirleri arasında az veya çok bağlantı bulunan iki kavramdan birinin diğerini temsil etmek amacıyla kullanılmasıdır. ${ }^{36}$ Örneğin, propaganda amaçlı posterde resmedilen gamalı haç taşıyan kişilerin Nazileri, orak ve çekiç taşıyan kişilerin de komünistleri çağrıştırması.

Çalışma amacı, Barthes'ın göstergebilimsel anlayışından ziyade, Barthes'ın düzanlam, yananlam ve mit olguları üzerinden İran-Irak Savaşı döneminde İran tarafından kullanılan propaganda amaçlı posterlerde inşa edilen söylemlerin çözümlenmesidir. Bu yüzden Barthes'1n göstergebilimsel anlay1şına çalışmada detaylı olarak yer verilmemiştir.

\section{Analiz}

Çalışmanın bu bölümde 8 propaganda amaçlı posterin göstergebilimsel analizi yapılmıştır.

İran-Irak Savaşı'nda, İran tarafından propaganda amaçlı kullanılan tüm posterler çalışmanın evrenini oluşturmaktadır. Buna karşın tüm posterlere ulaşmanın mümkün olmaması nedeniyle çalışmada örneklem kullanılması yoluna gidilmiştir. Çalışma kapsamında, Chicago Üniversitesi tarafından belirlenen İran-Irak Savaşı'nı konu alan 8 propaganda amaçlı poster ("Humeyni ile Beş Asker", "Bombalanan Binada Oturan Asker", "Kalplerin Cenazesi”, “Ölü Askeri Kucaklayan Çocuk”, “Molla, Anne, Asker”, "Irak

36 Peirce Guiraud, Göstergebilim. Çev., Mehmet Yalçın. 3. Baskı (Ankara: İmge Kitabevi, 2016), 145-146. 
Jetini Parçalayan Yumruk", "Saddam İçin Bir Görev", "Humeyni Kontrolündeki İran Petrol Tesisleri”) çalışma kapsamında incelenmiştir. ${ }^{37}$

\section{1. "Humeyni ile Beş Asker" Adlı Propaganda Posteri}

"Humeyni ile Beş Asker" adlı propaganda posteri düzanlam boyutunda ele alındığında, posterdeki görsel kodlar içerisinde beş askerin ve beş askerlerin hemen arkasında da Humeyni'nin resmedildiği görülmektedir. Kinetik göstergeler içerisinde yer alan beden dili ve jestlerinden, askerlerin karar11 bir şekilde belirsiz bir yöne doğru ilerledikleri izlenimi verilmektedir. Humeyni'nin resminin bir tarafında petrol bölgesi, diğer tarafında da tank görseli bulunmaktadır.

Resim 1: "Humeyni ile Beş Asker” Adlı Propaganda Posteri

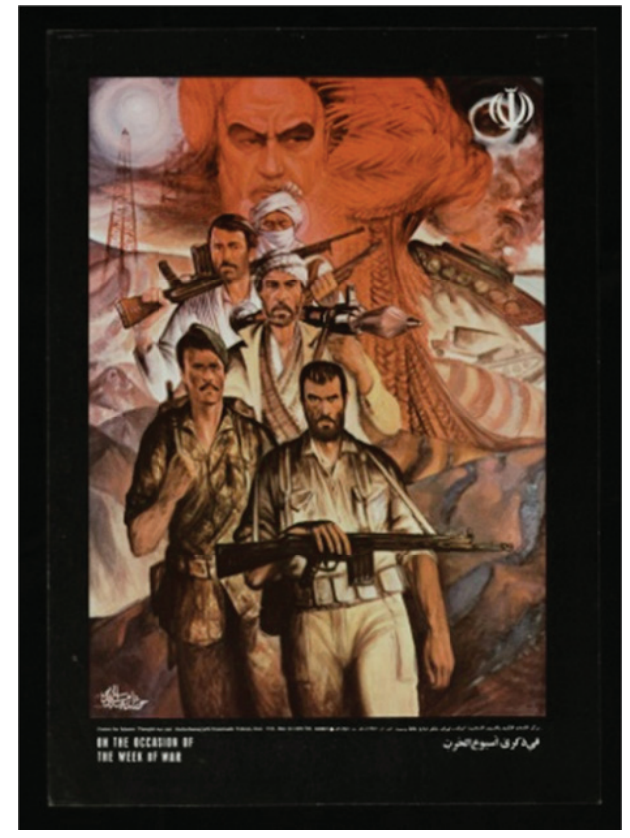

37 Chicago University, "İran İslam Devrimi Propaganda Amaçlı Posterler” https://www. lib.uchicago.edu/collex/exhibits/graphics-revolution-and-war-iranian-poster-arts/ holy-defense/. 09.08.2010. 
İran propagandasında milliyetçi söylemler sıklıkla kullanılmaktaydı. Humeyni yönetimi, İran'ın tüm etnik yapısını bir araya getirerek vatan savunması için seferber etmekteydi. ${ }^{38}$ Humeyni'nin resminin çevresinde konumlandırılan petrol tesisi ve tank görseli, İran-Irak Savaşı'nın metonimi olarak yer bulmaktadır. Yananlam boyutunda ele alındığında, posterde $\mathrm{Hu}-$ meyni önderliğinde İran halkının Irak Ordusu'na karşı topyekun savaştığ anlatılmaktadır. Nitekim görsel kodlarda beş farklı kıyafetler içinde sunulan askerler, İran'ın farklı etnik topluluklarının metonimi olarak yer almaktadır. Böylece İran halkının, Irak'a karşı tek vücut olarak savaştığı mesajı verilmek istenmektedir. Humeyni'nin askerlerin arkasında resmedilmesi, Humeyni'nin "koruyucu" metaforu olarak sunulmasına yol açmaktadır. Diğer yandan askerlerin Humeyni'nin önünden yürümeleri, İran halkının Humeyni için savaştığı izlenimini oluşturmaktadır. Sonuç olarak posterde, tüm İran halkının Humeyni'nin telkinleri doğrultusunda hareket ettiği şeklinde propaganda miti inşa edilmektedir. İnşa edilen mit ile, İran propagandası savaşta çıkabilecek muhtemel isyanları engellemek istemekte ve ülke içerisinde mutlak kontrolü sağlamayı amaçlamaktadır.

\section{2. "Bombalanan Binada Oturan Asker" Adlı Propaganda Posteri}

"Bombalanan Binada Oturan Asker" adlı propaganda posteri düzanlam boyutunda ele alındığında, posterde yıkıntılar içerisinde beklemekte olan bir İran askeri gösterilmektedir. Posterde, hava sarı renk içerisinde sunulmaktadır. Posterde görsel kodlar içerisinde siyah tonlar ağırlıklı olarak kullanılmıştır. Posterin hemen altında İngilizce İran'ın direnişi her ne pahasına olursa olsun sürdüreceği aktarılmaktadır. Poster, incelenen diğer posterler içerisinde doğrudan İngilizce açıklamaya yer veren tek posterdir.

38 Gary Sick, “Trial by Error: Reflections on the Iran-Iraq War". Middle East Journal 43, no.2, (1989): 234. 
Resim 2: "Bombalanan Binada Oturan Asker" Adlı Propaganda Posteri

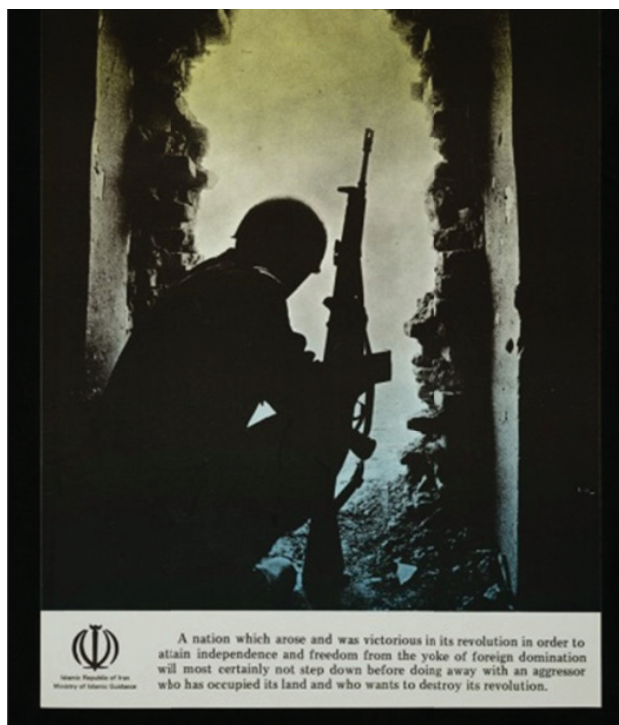

Savaşta Irak Ordusu'nun, İran'a karşı üstünlük elde edebilmek için kullandığı iki önemli silahı bulunmaktaydı: kimyasal silahlar ve füzeler. Irak'ın kimyasal silah kullanması İran'da paniğe yol açmaktaydı. ${ }^{39}$ Buna karşın ABD, Irak'1n uluslararası yasalara aykırı olarak kimyasal silah kullanmasına karşı çıkması gerekirken, baskısını İran üzerine yöneltmekteydi. ${ }^{40}$ Diğger yandan Irak tarafından kullanılan İran'a yönelik füzeler de İran Cephesi'nde büyük tahribata neden olmaktayd1. ${ }^{41}$ Tüm bunlara karşın her iki silahta savaşın Irak lehine sonlanmasına yeterli olmadı. Posterde yer alan asker, İran Ordusu'nun metonimi olarak kullanılmaktadır. Y1kıntılar içerisinde bulunan alan da, Irak Ordusu tarafından bombalanan İran binalarının metonimidir. Görsel kodlar içerisinde havanın sarı şekilde sunulması, Irak Ordusu'nun kimyasal silah kullandığını ifade etmektedir. Posterde, yananlam boyutunda İran Ordusu'nun kimyasal silah saldırısı altında Irak Ordusu'na karşı vermiş olduğu mücadele anlatılmaktadır. Yıkıntılar içerisinde bekleyen asker, posterde "kahraman" metaforu olarak sunulmakta-

39 L. Thomas McNaugher, "Ballistic Missiles and Chemical Weapons: The Legacy of the Iran-Iraq War”. International Security 15, no.2, (1990): 8.

40 Adam Tarock, The Superpowers' Involvement in the Iran-Iraq War (USA: Nova Publishers, 1998), 121.

$41 \quad$ McNaugher, "Ballistic" 13. 
dır. Görselde koyu tonlar kullanılması savaşın korkutucu yönünü ortaya çıkarmaktadır. Posterde tüm İran halkının savaşı sürdürmeye devam ettiğine yönelik propaganda miti inşa edilmektedir. Böylece inşa edilen mit ile birlikte, İranlıların savaş istemediğine ve teslim olmayı düşündüklerine yönelik yapılan propaganda faaliyetlerinin de önüne geçilmesi amaçlanmiştır.

\section{3. "Kalplerin Cenazesi” Adlı Propaganda Posteri}

"Kalplerin Cenazesi" adlı propaganda posteri düzanlam açısından incelendiğinde, posterde fiktif görsellerin kullanıldığı görülmektedir. Görsel kodlar içerisinde erkekler, kalplerinin içinde bulunduğu bir tabutu taşımaktadır. Erkeklerin beden dili ve jestlerinden üzüntü ve karamsarlık içerisinde oldukları görülmektedir. Posterde diğerlerinde olduğu gibi koyu tonlar hakimdir. Posterde verilmek istenen mesaj, hiç bir yazılı kod kullanılmadan doğrudan görsel kodlar içerisinde sunulmaktadır.

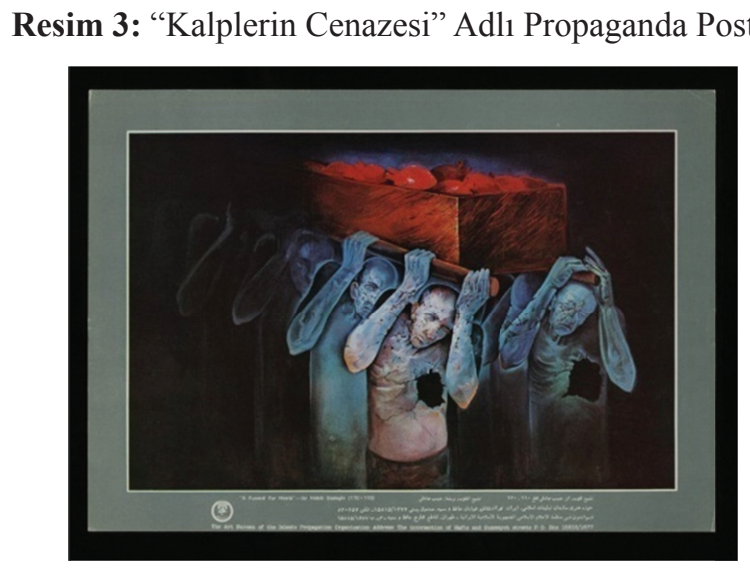

İran-Irak Savaşı'nda tarafların birbirlerine karşı üstünlük sağlayamamalar1, savaşın uzun süren bir yıpratma savaşına dönümesine yol açtı. Bu da savaşın her iki taraf içinde acımasız bir boyut kazanmasına yol açtı. ${ }^{42}$ Pos-

42 D. Will Swearingen, "Geopolitical Origins of the Iran-Iraq War". Geographical Review, (1988): 408. 
terde yer alan insanlar, Irak Ordusu'nun saldırısına maruz kalan ve zarar gören İran halkının metonimisi olarak kullanılmaktadır. Yananlam boyutunda kalplerin tabuta yerleştirilmesi, İran halkının savaşta büyük acılar çektiğine vurgu yapmaktadır. Diğer yandan kalplerinin içinde bulunduğu tabutu kendilerinin taşıması da, acılarını yalnız başlarına yaşadıklarına vurgu yapmaktadır. Görsel kodlar içerisinde kalp, "acı" ve "hüzün” metaforu olarak posterde yer bulmuştur. Posterde siyah tonların kullanılması da görselde verilmek istenen hüzün mesajını kuvvetlendirmektedir. Sunum kodları içerisinde tüm İran halkının Irak Ordusu'nun saldırıları sonucu büyük bir acı yaşadığına yönelik propaganda miti inşa edilmektedir. İnşa edilen mit ile İran halkının Saddam yönetimine karşı daha kararlı ve istekli savaşmaları istenmiştir. Böylece, İran'ın savaşta yaşadığı acıların, ülkede kenetlenmeye yol açacağı amaçlanmıştır.

\section{4. “Ölü Askeri Kucaklayan Çocuk” Adlı Propaganda Posteri}

“Ölü Askeri Kucaklayan Çocuk” adlı propaganda posteri düzanlam boyutunda ele alındığında, posterde hayatını kaybeden bir askere sarılmış olan küçük bir çocuk tasvir edilmektedir. Ölen askerin kanı üzerinde bulunduğu toprağa akmaktadır. Askerin düşen silahını yanındaki küçük çocuk tutmaktadır. Asker ve çocuğun hemen yanında ise göğe iki elin yükseldiği görülmektedir. Ellerden birinde bayrak bulunmaktadır. Diğer görsellerde olduğu gibi posterde koyu tonlar hakimdir.

Resim 4: “Ölü Askeri Kucaklayan Çocuk” Adlı Propaganda Posteri

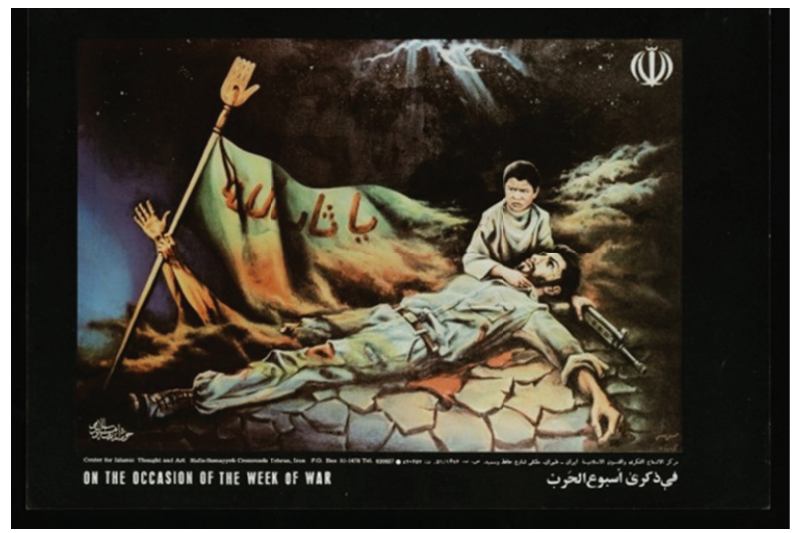


Humeyni yönetimi, propagandasında dini söylemlere sıklıkla yer vermekteydi. ${ }^{43}$ Posterde; hayatını kaybeden asker İran Ordusu'nun, askeri kucaklayan çocuk ise babasını savaşta kaybedip yetim kalan İranlıların metonimi olarak kullanılmıştır. Yananlam boyutunda, görsel kodlar içerisinde ölen askerin Cennet'e gideceği mesajı verilmektedir. Ölen asker, görsel kodlarda "kahraman" metaforu olarak sunulmaktadır. Askerin kanının toprağa dökülmesi ile Humeyni önderliğinde kurulan İran İslam Cumhuriyeti'ne kutsiyet kazandırılmaya çalışılmaktadır. Ölen askeri kucaklayan çocuğun jestlerinin üzüntüden çok kızgınlık içinde sunulması, ölen askerin yerine savaşa katılabileceği algısını oluşturmaktadır. Nitekim İranlı pek çok küçük çocuk Irak Ordusu'na karşı savaşa katılmıştı. Sunum kodları içerisinde görselde Irak Ordusu'na karşı savaşan ve hayatını kaybeden İran askerlerinin cennete gittiğine yönelik propaganda miti inşa edilmektedir. Böylece İran propagandası İran Ordusu'nun, Irak'a karşı daha istekli savaşmalarını sağlamayı amaçlamıştır. Diğer yandan, İranlıların hayatlarını kaybedenlerin intikamlarını almak için daha istekli ve şevkle savaşı sürdürmeleri amaçlanmıştır.

\section{5. "Molla, Anne, Asker" Adlı Propaganda Posteri}

"Molla, Anne, Asker" adlı propaganda posteri düzanlam açısından ele alındığında, posterde görsel kodlar içerisinde bir kadın ve üç erkeğin sunulduğu görülmektedir. Sunum kodları içerisinde kadın siyah bir çarşaf, iki erkek asker, bir erkek ise molla kıyafetleri içerisinde aktarılmaktadır. Askerden biri kitap, bir diğeri de silah tutmaktadır. Silahın üzerinde beyaz bir güvercin bulunmaktadır. Kadının ise bir elinde bebek, diğer elinde de bir çiçek yer almaktadır. Görselde kullanılan kişilerin dördü de beden dili ve jestleri ile bir şeyi hedef aldıklarını göstermektedir.

43 Gary Sick, "Trial by Error: Reflections on the Iran-Iraq War". Middle East Journal 43, no.2, (1989): 234. 
Resim 5: "Molla, Anne, Asker” Adlı Propaganda Posteri

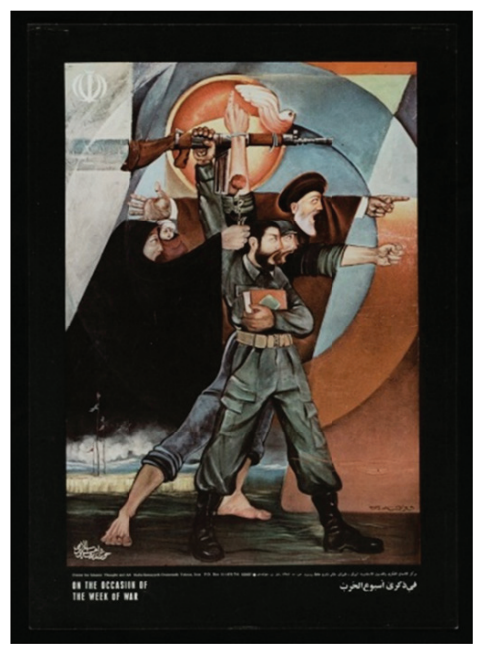

İran propagandası, İran-Irak Savaşı'nı yeni kurulan rejimin ülkede pekiştirilmesi için kullandı. Nitekim, Humeyni yönetimi dini ve ulusal söylemlerini ön plana çıkararak, İran halkını Irak’a karşı vatanlarını savunmaları için seferber etmeye çalıştı. ${ }^{44}$ Posterde yer alan iki asker İran Ordusu'nu, siyah çarşaf içerisindeki kadın İranlı kadınları, molla da İran'daki tüm mollaların metonimi olarak kullanılmıştır. Yananlam boyutunda her üç grubun bir arada gösterilmesi ile birlikte İran'ın kurtuluşunda İran ordusunun, yeni rejim tarafından idealize edilen siyah çarşaflı kadınların ve mollaların ön planda olduğu mesajı verilmektedir. Her üç grup da "kahraman" metaforu olarak görselde sunulmaktadır. Sunum kodları içerisinde kadının elinde yer alan bebek doğumu, çiçek de ölümü temsil etmektedir. Askerin tüfeğinin üzerinde bulunan beyaz güvercin de "özgürlük" metaforu olarak kullanılmaktadır. Posterde tüm İran halkının birlik içerisinde Irak’a karşı mücadele ettiği propaganda miti inşa edilmektedir. İnşa edilen propaganda miti ile İranlıların birlik ve beraberlik içerisinde savaşmaları amaçlanmıştır. Nitekim, Humeyni yönetiminin idealize ettiği karakterlerin propaganda amaçlı posterde resmedilmesi, İran'da savaşın Humeyni yönetimine sağdık yurttaşlar tarafindan sürdürüldüğü mitinin de ortaya çıkarılmasına yol açmaktadır. Bu yolla, İran-Irak Savaşı, Humeyni'ye ve yönetimine sadakatin bir göstergesi olarak sunulmaya çalışılmıştır.

44 Dilip Hiro, The Longest War: The Iran-Iraq Military Conflict (New York: Psychology Press, 199), 2. 


\section{6. "Irak Jetini Parçalayan Yumruk" Adlı Propaganda Posteri}

"Irak Jetini Parçalayan Yumruk" adlı propaganda posteri düzanlam boyutunda ele alındığında, posterde devasa boyutta bir elin bir jeti parçaladığ görülmektedir. Görsel kodlar içerisinde elin parçaladığ 1 jet, Irak Ordusu'na ait olduğu aktarılmaktadır. Jetin üzerinde ABD ve Sovyetler Birliği'ni simgeleyen bayraklara yer verilmektedir. Posterde diğer posterlerin aksine daha açık tonlar kullanılmıştır.

Resim 6: "Irak Jetini Parçalayan Yumruk" Adlı Propaganda Posteri

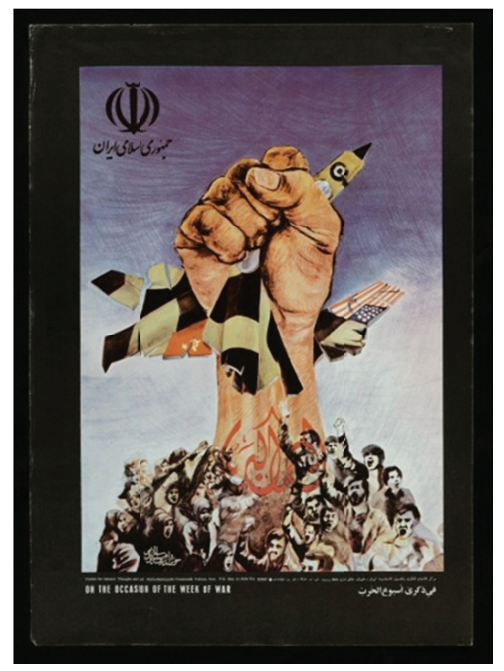

Irak Hava Kuvvetleri, Arap-İsrail Savaşları'na katılmıştı ve savaşta hava saldırıları konusunda deneyim elde etmişti. Benzer şekilde Irak Hava Kuvvetleri, İran-Irak Savaşı'nda da İran'da hedeflenen noktalara karşı saldırılar düzenlemekteydi (Bergquist, 1988: 57). Posterin merkezinde konumland1rilan havaya kalkan yumruk, İran İslam Devrimi'nde Humeyni taraftarlarının simgesi olarak kullanılmıştı. Yananlam boyutunda yumruğun Irak Ordusu'na ait jeti parçalaması, İran'da Humeyni taraftarlarının Şah'a karş1 kazandıkları zaferin benzerini Irak Ordusu'na karşı kazanacaklarını ifade etmektedir. Yumruğun altında yer alan insanlar, Humeyni'ni taraftarlarının metonimi olarak görselde yer almaktadır. Sunum kodları içerisinde havaya kalkan yumruk, "güç" ve "zafer" metaforu olarak kullanılmaktadır. Yumruğun parçaladığı jet Irak Ordusu'na ait olmasına karşın, Jetin üzerinde 
$A B D$ ve Sovyetler Birliği’nin bayraklarının kullanıldığ 1 görülmüştür. $\mathrm{Bu}$ yolla Irak Ordusu'nun ABD ve Sovyetler Birliği'nin desteği ile hareket ettiği propaganda miti inşa edilmeye çalışılmaktadır. İnşa edilen propaganda amaçlı mit ile İran yönetimi, İran'da hem ABD hem de Sovyetler Birliği karşıtlarını Irak aleyhine yöneltmeyi amaçlamaktadır. Bu yolla Irak Ordusu'nun İran karşıtları tarafından desteklendiği, İran'ın Irak'tan ziyade $A B D$ ve Sovyetler Birliği ile savaş halinde olduğu mesajı kitlelere aktarılmaya çalışılmıştır.

\section{7. "Saddam İçin Bir Görev" Adlı Propaganda Posteri}

"Saddam İçin Bir Görev" adlı propaganda posteri düzanlam açısından değerlendirildiğinde, posterde görsel kodlar içerisinde İran haritası üzerinde kapana kısılmış bir fare resmedilmektedir. Görselde sağ üstünde "Saddam İçin Bir Görev" şeklinde yazılı kod yer almaktadır.

Resim 7: “Saddam İçin Bir Görev” Adlı Propaganda Posteri

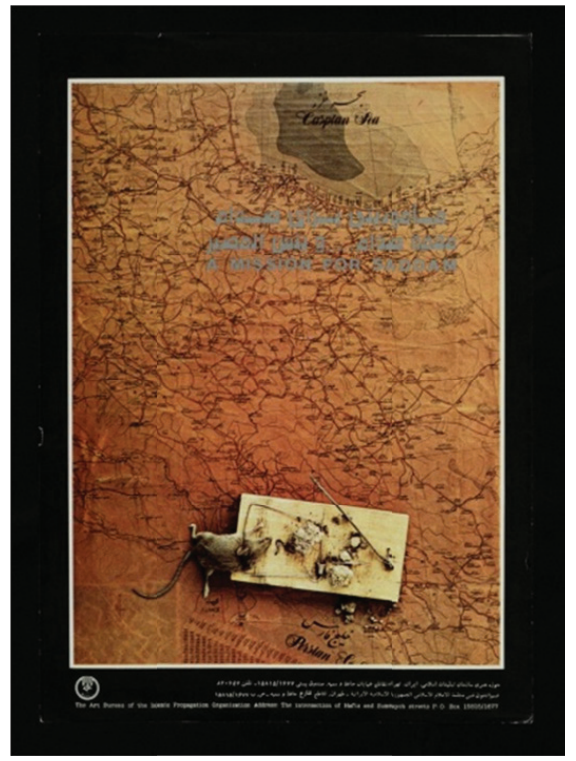


İran propagandası, Irak'ta doğrudan Saddam'1 hedef almaktaydı. Bu amaçla propaganda faaliyetleri Saddam'a yönelik nefret söylemi inşa etmek üzere kurgulanmaktayd.$^{45} \mathrm{Bu}$ posterde de, doğrudan Saddam hedef alınmaktadır. Posterde, Saddam kapana kısılan bir fare olarak sunulmaktadır. Kapanın İran haritasının üzerinde konumlandırılması da yananlam boyutunda Saddam'ın İran topraklarında büyük bir hezimete uğrayacağını ifade etmektedir. Posterde, Saddam ve ordusu "başarısızlık" metaforu olarak sunulmaktadır. Posterde Saddam'ın İran-Irak Savaşı'nı kaybedeceğine yönelik propaganda miti inşa edilmektedir. İnşa edilen mit ile İran propagandası, İran'ın Irak'tan daha güçlü olduğuna İran halkını inandırmayı amaçlamıştır. Böylece İran halkının Irak Ordusu ile daha kararlı bir şekilde savaşması istenmiştir. Diğer yandan İran'ın savaşı kaybedeceğine yönelik yapılan her türlü karşı propaganda faaliyetinin de önlenmesi hedeflenmiştir.

\section{8. "Humeyni Kontrolündeki İran Petrol Tesisleri” Adlı Propaganda Posteri}

"Humeyni Kontrolündeki İran Petrol Tesisleri" adlı propaganda posteri düzanlam açısında değerlendirildiğinde, posterde İran petrol tesisleri konu edilmektedir. Görsel kodlar içerisinde petrol tesislerinin hemen arkasında Humeyni'nin büyük bir resmi kullanılmıştır. Diğer yandan görselin solunda bir yılan, petrol tesislerindeki bir boruya sarılmış halde gösterilmektedir. Yılanın üzerinde Sovyetler Birliği’ni simgelemek amacıyla Sovyetler Birliği’nin bayrağı kullanılmıştır. Görselin sağında ise uzun tırnakları ile bir canavara ait olduğu izlenimi veren bir kol petrol tesislerine uzanmaktadır. Elin üzerinde ABD'yi simgelemek amacıyla ABD bayrăğ kullanı1mıştır. Yılan, bir mızrak ile öldürülürken, canavara ait kol bir mızrak ile kesilmektedir. Görselin tam merkezinde "Allah büyüktür" yazılı kodu yer almaktadır. Posterin sağ üstünde ise "Müslüman dünyası birleşirse, tüm İslam kaynakları üzerindeki büyük güçlerin etkisi ortadan kalkacaktır" şeklinde diğer bir yazılı koda yer verildiği görülmektedir.

\footnotetext{
45 M. S. El-Azhary, The Iran-Iraq War (RLE Iran A) (London: Routledge, 2011), 1.
} 
Resim 8: "Humeyni Kontrolündeki İran Petrol Tesisleri” Adlı Propaganda Posteri

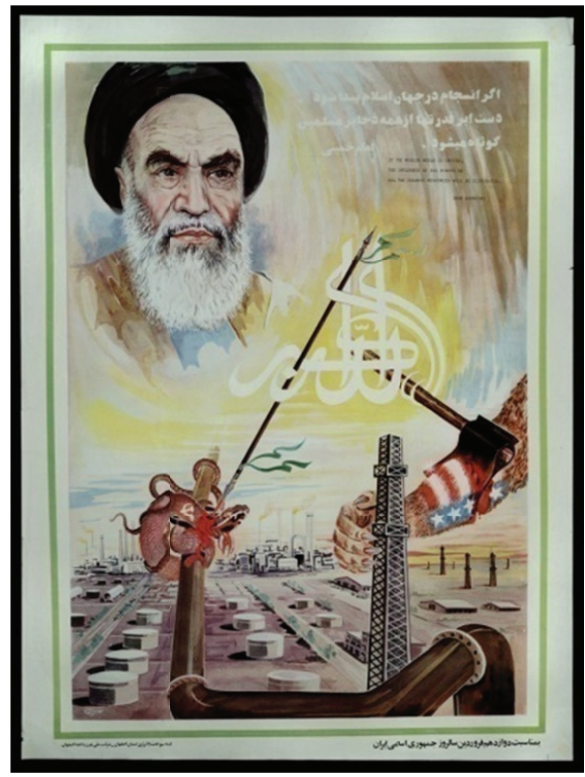

Irak'ın İran saldırısına zemin hazırlayan, İran'ın Huzistan'da elinde bulundurduğu zengin petrol bölgeleriydi ${ }^{46}$ Irak Ordusu petrol bölgesini ele geçirmek amacıyla İran'a saldırıya geçmişti. Bu açıdan postere konu edilen İran petrol tesisleri, İran-Irak Savaşı'nın çıkmasının temel sebeplerinde biridir. Yananlam boyutunda petrol tesislerini ele geçirmek isteyen asıl gücün Irak'tan ziyade ABD ve Sovyetler Birliği olduğu mesaj1 verilmektedir. Nitekim görsel kodlar içerisinde ABD bayrağı ile simgelenen canavar ve Sovyetler Birliği bayrağı ile simgelenen yılanın petrol tesislerini ele geçirmeye çalıştığ 1 gösterilmektedir. ABD ve Sovyetler Birliği posterde "işgalci” metaforu olarak kullanılmaktadır. Posterde İran'1 asıl ele geçirmek isteyenlerin $\mathrm{ABD}$ ve Sovyetler Birliği olduğu propaganda miti inşa edilmeye çalışılmıştır. İnşa edilen propaganda amaçlı mit ile Humeyni yönetiminin hedefinde bulunan ABD ve Sovyetler Birliği'ne karşı İran kamuoyunda nefret söylemi inşa edilmeye çalışılmıştır. Görsel kodlar içerisinde yılanın mizrak ile canavarın da balta ile durdurulması, yananlam boyutunda

46 El-Azhary, The Iran, 3. 
İran'ın Irak'a ve onu destekleyenlere verdiği mücadeleyi konu edinmektedir. Mızrak ve baltanın arkasında "Allah büyüktür" yazısına yer verilmesi dini söylemlerin propaganda amaçlı postere yansımasıdır. Bu yolla İran, halkının savaşma isteğini arttırmaya çalışmaktadır. Görselde yer alan "Müslüman dünyası birleşirse, tüm İslam kaynakları üzerindeki büyük güçlerin etkisi ortadan kalkacaktır" yazılı kodu ile İran'ın içindeki ve d1şındaki tüm Müslümanların emperyalist güçlere karşı birlik olması gerektiği vurgulanmaktadır. Nitekim, İran-Irak Savaşı'nın temel nedenlerinden biri de Sünni-Şii çatışmasıydı. İran, birlik mesajı vererek Müslümanların mezhepsel çatışmalara son vererek asıl kaynaklarını ele geçirmek isteyen büyük devletlere karşı ortak hareket etmesi gerektiğini vurgulamaktadır.

\section{Sonuç}

Çalışma kapsamında İran-Irak Savaşı'nda, İran tarafından propaganda amaçlı kullanılan posterler göstergebilimsel analiz yöntemi kullanılarak incelenmiştir. İncelenen posterlerde genel olarak İran halkının ön plana çıkarıldığı görülmüştür. Posterlerde, İran İslam Cumhuriyeti Lideri Humeyni'nin görselleri ile bütünleştirilen İran halkının tüm kesimlerinin Irak'a karşı bir araya geldiği vurgulanmıştır. Görsellerde Humeyni'nin sürekli olarak kullanılması ile İran-Irak Savaşı'nda Humeyni'nin İran halkı gözünde kült lider olarak inşa edilmesi amaçlanmıştır.

Posterlerde Irak'a yönelik Irak Devlet Başkanı Saddam Hüseyin üzerinden nefret söylemi inşa edildiği görülmektedir. Diğer yandan görsellerde sıklıkla ABD ve Sovyetler Birliği'nin hedef alındığı, Irak Ordusu'nun iki süper güç tarafından finanse edildiği vurgulanmıştır. Her iki devletinde de Irak'1 kullanarak İran petrol bölgelerini ele geçirmeye çalıştığı üzerinde durulmuştur. Bu yolla İran halkının, Irak gibi Şii nüfusun çoğunlukta olduğu bir ülkeden ziyade, gerçekte kapitalist $\mathrm{ABD}$ ve komünist Sovyetler Birliği'ne karşı savaştığı mesajı verilmeye çalışmaktadır. Böylece İran halkının savaşma isteğinin arttırılması amaçlanmıştır.

İran halkının metonimileri sıklıkla posterlerde yer edinmiştir. Buna karşın Irak'a yönelik sınırlı sayıda metonimiye yer verildiği görülmektedir. İran halkını temsil eden metonimilerde de İran halkının "kahraman" şeklinde olumlu metaforlar üzerinden sunulduğu görülmüştür. Bu açıdan, İran'ın propaganda amaçlı posterlerinde ilk hedefinin -İran'daki Humeyni muha- 
lifferi de dahil olmak üzere- tüm İran halkının Irak Ordusu'na karşı topyekun savaşması olduğu bulunmuştur. İran İslam Devrimi'nde devrimcilerin simgesi haline gelen "havaya kalkan yumruk" işareti posterlerde sürekli olarak kullanılmıştır. Böylece devrimde Şah yönetimine karşı olduğu gibi aynı direnişin Irak'a karşı da yürütüldüğü mesajı verilmek istenmiştir. Ayrıca posterler genel olarak verilmek istenen mesajları görsel kodlar içerisinde sunmakta, yazılı kodlara ise sınırlı oranda yer vermektedir. Böylece propagandanın temel özelliği olan kısa ve net bilgi stratejisinden yararlanılmaya çalışıldığı, kitleler nezdinde propaganda mesajının daha etkili sunulması amaçlandığı görülmüştür.

Propaganda amaçlı oluşturulan posterlerde; tüm İran halkının Humeyni'nin önderliğini kabul ettiği, İran halkının asla teslim olmayacağı, Irak Ordusu'nun ABD ve Sovyetler Birliği tarafından desteklendiği, savaşta hayatını kaybeden İran askerlerinin cennete gideceği, Irak'ın kimyasal silah kullandığı, İranlı sivillerin savaşta büyük acılar çektiği, İran'ın savaşı kazanacağı gibi propaganda mitlerinin inşa edilmeye çalışıldığı görülmüştür. Böylece İran, dini ve ideolojik söylemlerini propaganda amaçlı oluşturulan posterlere doğrudan yansıtmıştır. Özellikle posterlerdeki sunum kodlarında, İran İslam Cumhuriyeti tarafından idealleştirilen siyah çarşaflı kadın ve sakallı erkek görselleri ön plana çıkarılmıştır.

Çalışmada ele edilen bulgular, İran-Irak Savaşı'nda İran'ın propaganda faaliyetlerini ortaya koyması bakımından büyük önem taşımaktadır. Çalışma yakın dönemde meydana gelen ve etkisi günümüzde hala hissedilen İranIrak Savaşı'nın propaganda faaliyetlerine 1şık tutması bakımından büyük önem taşımaktadır. Buna karşın gelecek çalışmaların İran-Irak Savaşı'nda Irak'ın propaganda faaliyetlerini ele alması alanın kaynak bakımından zenginleşmesini sağlayacaktır.

\section{Kaynakça}

Abrahamian, Ervand. Modern Iran Tarihi, Çev. Dilek Şendil. 2. Baskı. İstanbul: Türkiye İş Bankası Yayınları, 2011.

Arpa, Murat. "İş Güvenliğini Konu Alan Kamu Spotu Reklamlarında Korku Çekiciliği Kavramının Kullanılması”, Uluslararası Sosyal Bilimler Dergisi, Cilt 1, Say1 2, (2018): 105-115. 
Barthes, Roland. Göstergebilimsel Serüven. Çev., Mehmet Rifat-Sema Rifat. 8. Bask1. İstanbul: Yap1 Kredi Yayınları, 2016.

Barthes, Roland. S/Z. Çev., Sündüz Öztürk Kasar. İstanbul: Sel Yayıncılık, 2016.

Batur, Sabire. Siyasal İslam Sineması Örneğinde İran Sineması Yayınlanmamış, Doktora Tezi: Dokuz Eylül Üniversitesi Güzel Sanatlar Enstitüsü, İzmir, 2007.

Bergquist, E. Ronald. The Role of Airpower in the Iran-Iraq War. Alabama: Air University Press, 1988.

Boyraz, Burak, \& Cantürk, Ali. “Amerika Birleşik Devletleri Örnekleminde İkinci Dünya Savaşı Dönemi Askeri Propaganda Posterleri”. Uluslararası Sosyal Araştırmalar Dergisi, 7(3), (2014): 496-503.

Çak1, Caner. “Birinci Dünya Savaşı'ndaki Alman Propaganda Kartpostallarında Kullanılan Karikatürlerde Türklerin Sunumunun Göstergebilimsel Açıdan İncelenmesi”. Akdeniz Üniversitesi İletişim Fakültesi Dergisi, (29), (2018): 73-94.

Çak1, Caner. "Sovyetler Sonrası Rus Sinemasında Komünizm İdeolojisi: Amiral Filmi ve Göstergebilimsel Analizi”. Uluslararası Sosyal Bilimler Dergisi, 1(1), (2018): 53-68.

Çak1, Caner. "Mitinglerin Propagandadaki Rolü: Nürnberg Mitingleri'ne Ait Fotoğrafların Göstergebilimsel Analizi”, Maltepe Üniversitesi İletişim Fakültesi Dergisi, 5 (1), (2018): 59-79.

Çakı, Caner ve Gülada, Mehmet Ozan "Vichy Fransası'nda İşgal Propagandası". Trakya Üniversitesi Iktisadi ve İdari Bilimler Fakültesi Dergisi, 7 (1), (2018): 53-80.

Çak1, Caner, Karaburun Doğan, Derya \& Yılmaz, Nurcan. Horst-Wessel Propaganda Marşı Üzerinden Nazizm İdeolojisinin İnşası. İletişim Kuram ve Araştırma Dergisi, (46), (2018): 89-110.

Çelik, Kadir Ertaç. "İslam Devrimi Sonrası İran'da Kimlik ve Dış Politika: Konstrüktivist Bir Bakış”. Bölgesel Çalışmalar, 1(1), (2016): 251-274.

Doster, Barış. "Bir Bölgesel Güç Olarak İran'ın Ortadoğu Politikası". Ortadoğu Analiz, 4(44), (2012): 44-51. 
El-Azhary, M. S. The Iran-Iraq War (RLE Iran A). London: Routledge, 2011.

Erol, E Gülbuğ, Cerrahoğlu, Necati \& Çakı, Caner. "Hitler Dönemi Eğitim Yapısındaki Otokrasinin Eleştirisi: Die Welle Filmi Üzerine Göstergebilimsel İnceleme", IX. Uluslararası Ĕgitim Araştırmaları Kongresi, Ordu, (2017): 1234-1249.

Fiske, John. İletişim Çalışmalarına Giriş. Çev., Süleyman İrvan. 5. Basım. Ankara: Bilim ve Sanat Yayınları, 2017.

Guiraud, Peirce. Göstergebilim. Çev., Mehmet Yalçın. 3. Baskı. Ankara: İmge Kitabevi, 2016.

Gündoğan, Ünal. "Geçmişten Bugüne İran İslam Devrimi: Genel Değerlendirme." Ortadoğu Analiz, 3(29), (2011): 93-99.

Gündoğan, Ünal. “1979 İran İslam Devrimi’nin Ortadoğu Dengelerine Etkisi”. Middle Eastern Analysis / Ortadogu Analiz, 3(30), (2011): 67-73.

Güngör, Nazife. İletişim Kuramlar ve Yaklaşımlar, 2. Baskı, İstanbul: Siyasal Kitapevi, 2013.

Hiro, Dilip. The Longest War: The Iran-Iraq Military Conflict. New York: Psychology Press, 1991.

İnanç, Gül. Türk Diplomasisi'nde Irak (1978-1997). İstanbul: Türkiye İş Bankası Yayınları, 2008.

Kalkan Kocabay, Hasibe. Tiyatroda Göstergebilim. İstanbul: E Yayınları, 2008.

Karsh, Efraim. "Geopolitical Determinism: The Origins of The Iran-Iraq War. "Middle East Journal, 44(2), (1990): 256-268

Karsh, Efraim. The Iran-Iraq War. USA: The Rosen Publishing Group, 2009.

McNaugher, L. Thomas. "Ballistic Missiles and Chemical Weapons: The Legacy of the Iran-Iraq War". International Security, 15(2), (1990): 5-34.

Pelletiere, C. Stephen. "The Iran-Iraq War: Chaos in a Vacuum”. USA: ABC-CLIO, 1992.

Ramazani, Rouhollah. "Revolutionary Iran: Challenge and Response in the Middle East" (Vol. 237). Baltimore: Johns Hopkins University Press, Vol. 40, No. 1, (1986): 111-114. 
Rifat, Mehmet. Açıklamalı Göstergebilim Sözlüğü: Kavramlar, Yöntemler, Kuramcılar, Okullar. İstanbul:Türkiye İş Bankası Kültür Yayınları, 2013.

Segal, David. "The Iran-Iraq War: A Military Analysis". Foreign Affairs, 66(5), (1988): 946-963.

Sığırc1, İlhami. Göstergebilim Uygulamalarl, Metinleri, Görselleri ve Olayları Okuma. Ankara: Seçkin Yayıncılık, 2016.

Sick, Gary. "Trial by Error: Reflections on the Iran-Iraq War". Middle East Journal, 43(2), (1989): 230-245.

Swearingen, D. Will. "Geopolitical Origins of the Iran-Iraq War". Geographical Review, (1988): 405-416.

Tanyeri Mazıcı, Emel ve Çakı, Caner. "Adolf Hitler'in Korku Çekiciliği Bağlamında Kamu Spotu Reklamlarında Kullanımı”. Erciyes Illetişim Dergisi. 5 (3). (2018): 290-306.

Tarock, Adam. The Superpowers' Involvement in the Iran-Iraq War. USA: Nova Publishers, 1998.

Yıldırım, Leman Nida. "1979 İran Devrimi Özelinde Muhafazakârlık İdeolojisinin Eleştirisi: Persepolis Filmi ve Göstergebilimsel Analizi”. Uluslararası Sosyal Bilimler Dergisi, 1 (1), (2018): 32-52.

Yurdakurban, İsmail. Devrim Sonrası İran Dış Politikası (1979-2005), Yayınlanmamış Yüksek Lisans Tezi, Selçuk Üniversitesi Sosyal Bilimler Enstitüsü, Konya, 2007.

İnternet Kaynakları

Chicago University, "İran İslam Devrimi Propaganda Amaçlı Posterler" https://www.lib.uchicago.edu/collex/exhibits/graphics-revolution-andwar-iranian-poster-arts/holy-defense/. 09.08.2010. 